\title{
CORRESPONDENCE.
}

THE (HALK AT GUILDFORD.

SIR,-It may be of interest to record the occurrence of Chalk of the Actinocamax quadratus zone at Guildford, as this is, I think, the only record of this zone on the North Downs apart from the reference by Barrois (Recherches sur le Terrain Crétacé supérieur de l'Angleterre et de l'Irlande, 1876, pp. 139-40) to the detection of Offaster corculum (Gold.) $[=$ Offaster pillu'a (Lam.) $]$ on the north of the Hogs Back.

At Guildford Park, about half a mile westward of the railway station, a $10 \mathrm{ft}$. sewer trench has recently been dug parallel to, and almost at, the junction of the Chalk with the Tertiary beds. This trench exposed Chalk in which both Marsupites and Uintacrinus were entirely absent, but which yielded Offaster pillula (Lam.) and many specimens of Echinocorys scutatus, which Mr. A. G. Brighton, who accompanied me on one of my visits to the section, identified as $E$. scutatus var. depressus Brydone.

H.M. Grobngleat. SERVEY.

F. H. Edmunds.

\section{THE OLD RED SANDSTONE OF THE WELSH BORDER.}

SIR,-I have read with much interest Mr. Fleet's paper on the petrology of the Old Red Sandstone of the Welsh Border. While the results of the investigation are themselves most suggestive, the interest of workers on sedimentary petrology will naturally centre on the account of the methods employed. Most workers agree that the frequency numbers based on eye estimation or on partial counts are far from ideal, though in the hands of experienced workers they have no doubt been of value. The opinion of these workers on Mr. Fleet's method will be awaited with interest.

My present purpose is simply to state that, at Mr. Fleet's instance, I have given his method a trial with most gratifying results. As noted by him it was applied to the examination of some Diestian sands at Sanderstead, but I have given it a more extended test in the case of certain High Level Pliocene deposits in the centre of the London Basin.

Over a small area the constancy of percentages for deposits of the same group is very striking and it is of definite diagnostic value. Over a wider area a significant regional graduation of the percentages can be detected-a regular increase in the percentage of stable species in the direction of transit of the material pointing to progressive elimination of the less resistant mineral types. The results of the investigation will, it is hoped, be published in due course, but meanwhile I take this opportunity of bearing testimony to the value of the method. 